The idea that it's going to provide a crystal ball that will personalize everyone's care is absurd. It will guide some important medical decisions and will be an important tool in our arsenal."

Of course, promises of personalized medicine don't seem so crazy in comparison with the outlandish claims occasionally made by some direct-to-consumer genetic testing companies. DNA testing has been offered to develop personalized perfumes and tailored diets, and even to assist the lovelorn in finding an exquisite, biologically compatible mate.

"While the desire for profit lies at the heart of this phenomenon, it must be recognized that it builds on the hype about the health value of genetic testing that often flows from the research community, the representations of hype that appears in the media and throughout popular culture, and the public expectations that are fueled by this hype," Timothy Caulfield, a Canada Research Chair in Health Law and Technology who teaches in the law faculty and school of public health at the University of Alberta in Edmonton, wrote in a commentary (JCOM 2011;10:C02).

"In the short term, everybody benefits from the hype," says Caulfield, adding that the abundance of unrealistic expectations shouldn't detract from the actual promise of genomics. "I have no doubt that we are going to see real benefits from the tremendous genetic research that's happening."

Actually, some of that research is already set for prime time, says Cinnamon Bloss, the lead investigator of the Scripps Genomic Health Initiative at the Scripps Translational Science Institute in La Jolla, California. "There are some aspects of genomics that are ready to help improve human health, and one area is pharmacogenics," says Bloss, referring the practice of assessing how individual genotypes will react to med- ication. "This will enable us to better dose a drug so it would better work for a person. If you know a person's genotype, you will also be better able to tell if they might have an adverse event."

Bloss adds that criticism of a genetic service as being clinically irrelevant doesn't mean it lacks value for patients, citing the concept of "personal utility." Even if, for example, a test reveals a predisposition for a condition with no treatment, some people still want that information and may live their lives differently as a result. Some consumer advocates argue that it is not up to the medical profession to decide if genetic information is useful or not.

"Is that a decision for someone else to make for me?" says Bloss. "Shouldn't I be able to decide if that information is useful? Those types of arguments are being made." — Roger Collier, CMAJ

CMAJ 2012. DOI:10.1503/cmaj.109-4142

\title{
Who should hold the keys to your DNA?
}

$\mathrm{C}$ an you handle the truth? Do you really want to know the secrets hidden beneath your skin, deep down in your DNA? There might be bad news in there, lurking in your genes, concealed in your proteins, skulking in your chromosomes.

These are questions more people will likely face as direct-to-consumer genetic tests fall in price and increase in sophistication. Many physicians and geneticists believe consumers shouldn't be answering those questions alone, suggesting that regulations are necessary to ensure medical professionals are part of the process. Critics of regulation disagree, claiming that doctors are being paternalistic and that consumers deserve uninhibited access to their own genetic information.

In the early days of retail genomics, more than a decade ago, there was much concern in the medical community that consumers would be unprepared to receive potentially devastating health news from genetic tests and would suffer great anxiety. That doesn't appear to have transpired, though it was not absurd, at the time, to think that it could, says Timothy Caulfield, a Canada Research Chair in Health Law and Technology.

"It was reasonable speculation. The thinking at the time was that people were going to be getting this information and it was going to be powerful. There would be anxiety. Perhaps people would make inappropriate health care decisions. To some degree, this drove the development of the whole field of genetic counselling," says Caulfield, who teaches in the Faculty of Law and the School of Public Health at the University of Alberta in Edmonton. "It turns out, and data is emerging to support this, that people don't get that anxious about it. Maybe a cohort of people does but, in general, there aren't those high levels of anxiety that people expected."

Prior to the proliferation of direct-toconsumer genetic tests, a systematic review of scientific literature about the mental hazards of genetic discovery uncovered few studies worth reading, though it was suggested that "those undergoing predictive genetic testing do not experience adverse psychological consequences" (Eur J Hum Genet 2000; 8:731-8). Little has changed in the ensuing dozen years, according to a recent study which found that consumers who purchase genetic tests suffer few anxiety symptoms. Over $90 \%$ of participants who completed follow-up reporting indicated that they suffered no test-related distress (N Engl J Med 2011;364:524-34).

"This type of test has been and remains extremely controversial for a variety of reasons. One is the direct-toconsumer nature of it. You get results without a physician and without a genetic counsellor," says Cinnamon Bloss, lead author of the more recent study and lead investigator for the Scripps Genomic Health Initiative at the Scripps Translational Science Institute in La Jolla, California. "Some people feel it is a medical test and that it should be interpreted by a health care professional, because people might see their test results and have anxiety if they don't understand them. Based on our data, people aren't having strong negative reactions in terms of anxiety."

In fact, many people indicate they would take predictive genetic tests "even in the absence of direct treatment consequences" and are "willing to pay reasonably large amounts for the opportunity," according to a random survey of 1463 
Americans (Health Econ 2012;21:23851). When presented with various disease scenarios, such as Alzheimer disease, arthritis, breast cancer or prostate cancer, $70 \%-88 \%$ of respondents were still inclined to take a genetic test.

"I think there is a need to think this through and to have some balance. On the one hand, we should respect consumers' preferences and freedom to choose," says Peter Neumann, director of the Center for the Evaluation of Value and Risk in Health at the Institute for Clinical Research and Health Policy Studies at Tufts Medical Center in Boston, Massachusetts and lead author on the paper. "We should also inform them about the risks and benefits."

In some countries, governments have stepped in to ensure that doctors are the ones who must inform consumers about risks and benefits. Laws in France, Germany, Portugal and Switzerland stipulate that genetic tests only be administered by physicians. There are no regulations in Canada and few in the United States, though the US Food and Drug Administration has indicated that it will be stepping up efforts in the area.

"I'm of two minds about this," says Caulfield. "If the general social anxiety isn't that big of a problem, maybe we don't need an aggressive regulatory response. On the other hand, I like the idea that regulators are putting their minds to this. We want to ensure, at minimum, that accurate information is getting to consumers."

Caulfield once surmised that policymakers who do turn their attention to genetic testing should perhaps pay less attention to the "creation-of-anxiety concern" and more to the impact "on the health care system, the possible promotion of unnecessary follow-up investigations, and the need to ensure truth in advertising" (Hum Genet 2011; 130:23-5).

Then again, patient anxiety levels might become of greater concern when the price of sequencing entire genomes falls to a level that makes it a reasonable consumer option, providing people with access to more, and potentially scarier, genetic information. haps those who showed early interest in their genomes suffered little mental anguish because they are more scientifically savvy than the general public, but a genetic test should still be "treated like the medical test it most assuredly is" and doctors should be involved in the process to, at very least, inform people of the risks of digging into their DNA.

As for whole-genome testing, it represents an "extraordinarily complex amalgam of multiple tests that can be at once useful, pointless, confusing, or overtly harmful," Evans once wrote while suggesting that physicians will have little choice but to grapple with how such tests should be applied and regulated (JAMA 2001;3306:2376-7).

"I'm not saying that people shouldn't have access to their genome or the information in it, but we shouldn't casually spew potentially disturbing information to people without some reasonable expectation that they have been educated about it. Physicians are often accused of being paternalistic, but we deal with complex information that can easily be misconstrued and cause harm," he says. "We have to be careful to do this is in a responsible way. I don't think that doing it in a responsible way is overly paternalistic." - Roger Collier, CMAJ seople who actively pursue certain genetic tests, and are highly educated about the results, and when the delivery of those results is done in a careful way, those individuals do not suffer untoward results," says Dr. James Evans, editor-in-chief of Genetics in Medicine and Bryson Distinguished Professor of Genetics and Medicine at the University of North Carolina in Chapel Hill.

Still, the potential exists for people to casually discover devastating information about their health, says Evans, and that is a legitimate concern.

While it would no doubt be easier for companies that sell genetic tests to reach consumers if they didn't have to first go through regulators or physicians, excluding the medical profession might be unwise, Evans explains. Per-

\section{CMAJ 2012. DOI:10.1503/cmaj.109-4141}

Editor's note: Second and third of a multipart series on genetic testing.

Part 1: Separating hype from reality in the era of the affordable genome (www.cmaj.ca/lookup/doi/10.1503 /cmaj.109-4143).

\section{Part 4: A race-based detour to personalized medicine} (www.cmaj.ca/lookup/doi/10.1503 /cmaj.109-4133).

Part 5: Race and genetics in the doctor's office (www.cmaj.ca/lookup /doi/10.1503/cmaj.109-4134). 


\section{More news online}

Separating hype from reality in the era of the affordable genome: Despite lofty promises about personalized medicine, humans aren't getting healthier (www .cmaj.ca/lookup/doi/10.1503/cmaj .109-4143). - Roger Collier, CMAJ

Health in Colombia: a system in crisis: Colombia's health care provides dramatically inferior care to the less affluent (www .cmaj.ca/lookup/doi/10.1503/cmaj .109-4124). - Paul Christopher Webster, Bogotá, Colombia

Health in Colombia: treating the displaced: (www.cmaj.ca/lookup /doi/10.1503/cmaj.109-4125). Paul Christopher Webster, Ciudad Bolívar, Colombia

Health in Colombia: the chronic disease burden: (www.cmaj.ca /lookup/doi/10.1503/cmaj.109-4126). - Paul Christopher Webster, Bogotá, Colombia

Calculating risk in use of disposable contact lenses: Manufacturers suggest improper use of contact lenses can lead to serious problems but many patients opt to ignore the risk (www.cmaj.ca/lookup /doi/10.1503/cmaj.109-4117). Roger Collier, CMAJ

Who should be privy to your privates?: Uncertainty about who should chaperone intimate examinations may be undercutting the protections such attendants may afford patients and doctors, experts say (www.cmaj.ca/lookup /doi/10.1503/cmaj.109-4129). Lauren Vogel, CMAJ

Advocacy groups continue to scorn screening guidelines: (www .cmaj.ca/lookup/doi/10.1503/cmaj .109-4147). — Lauren Vogel, CMAJ

CMAJ 2012. DOI:10.1503 /cmaj.109-4150 